\title{
Yes! There is an ethics of care: an answer for Peter Allmark
}

\author{
Ann Bradshaw National Institute for Nursing, Radcliffe Infirmary, Oxford
}

\begin{abstract}
This paper is a response to Peter Allmark's thesis that 'there can be no "caring" ethics'. It argues that the current preoccupation in nursing to define an ethics of care is a direct result of breaking nursing tradition. Subsequent attempts to find a moral basis for care, whether from subjective experiential perspectives such as described by Noddings, or from rational and detached approaches derived from Kant, are inevitably flawed. Writers may still implicitly presuppose a concept of care drawn from the fudaeo-Christian tradition but without explicit recourse to its moral basis nursing is left rudderless and potentially without purpose. The very concept of 'care' cut off from its roots becomes a meaningless term without either normative or descriptive content.
\end{abstract}

\section{Introduction}

Peter Allmark, a teacher of nurses, in a recent awardwinning article published in the anniversary edition of the fournal of Medical Ethics (1) has concluded that 'there can be no "caring" ethics' (2). He argues that the idea of an ethics based on concepts of care and caring has developed in the last ten years particularly in nursing, but that this term has no meaning. The concept of care itself has no moral import; it is cognitive and emotional but is without intrinsic value. Care, according to Allmark, has neither normative nor descriptive content. It merely denotes what is important to us.

In this paper I will attempt to show that Allmark's conclusion is a natural result of the breaking of a tradition in which care was seen as a fruit of faith and a moral imperative. 'I was hungry and you gave me food, I was thirsty and you gave me drink, I was a stranger and you welcomed me, I was naked and you clothed me, I was sick and you visited me, I was in prison and you came to me' (3). This was the basis of care for others, the underpinning of nursing and medicine; the inspiration for the first hospitals in the East, the work of Florence Nightingale, Cicely

\section{Key words}

Care; caring ethics; nursing; tradition.
Saunders and hence, the modern hospice movement $(4,5)$. Care was no mere ethical discourse or idea; it was incarnated, lived out, practical action.

But we must also assess and clarify Raanan Gillon's statement (6) that 'mature medical morality has since Hippocratic times incorporated at its centre a moral concern for nurturing and care for its sick patients; meeting the needs of sick patients has been the moral driving force of medical ethics since its inception' (7).

In his Harveian Oration given at the Royal College of Medicine in 1990, Lord Walton of Detchant describes how Christianity decisively influenced the Hippocratic tradition (8). Hippocrates, Socrates, Plato and Aristotle all taught on the doctor-patient relationship. Fundamental to this was the concept of philia, both for the patient and the art of medicine. The Greek doctor developed a relationship with his patients influenced first by his love of man and secondly by love of his art. But philia for the patient or philanthropy was very much related to man in the abstract and not to individual patients. 'Differential treatment was given to the rich, to the poor but free, and to slaves, the latter being treated only by the doctor's assistant with minimal individual attention' (9).

Despite their belief in disease prevention and health education, the Greeks only seemed to consider that discussions on lifestyle and causes of disease would benefit the rich. Such discussions were not considered appropriate for slaves and artisans. It was thought unethical for a doctor to treat a patient with a deadly disease, for this challenged nature and the gods and the doctor would risk paying the penalty. 'Thus in the Hippocratic tradition the doctor did not treat the incurably sick or terminally ill' (9). He also made moral judgments in that no wise doctor would treat anyone living an immoral life.

Under Christian influence the philia of the Greeks concentrated on anthropos rather than technie. Love for man in nature was transformed into love for thy neighbour and the doctor became concerned to treat all his patients irrespective of class, status, or ability to pay, whether in coin or kind. The Christian ethic also required that the doctor's task now involve the care and consolation of the terminally ill. 
So care was a prerequisite for both the development of nursing and medicine, although it is nursing, particularly, as it embraces the quintessential purpose of care, that will be my focus. The locus where care has traditionally been taken for granted as the central manifestation reveals most clearly the current dilemma. No longer is it taken for granted by modern nursing. Now nursing is asking the previously unthinkable. What is the meaning of 'care'? And Allmark's paper, in a nutshell, seems to reveal the truth of the theologian Hendrikus Berkhof's statement, that when the gospel fruit is picked from the gospel tree it can no longer remain the same (10). What Allmark shows us is this: care shorn of its original meaning becomes meaningless. Nursing, especially, taken from its 'lamp tradition' (5) no longer has a basis for its activity. Allmark is right, for when care ceases to be clear as caritas or agape, then what is it but a neutral form of concern with what matters to the self? Care is nothing more than selfconcern. But he is wrong in assuming that there can therefore be no ethics of care. The answer lies in what so much of nursing denies, the tradition. But before I turn to this tradition, I will examine the current understandings of care, looking with Allmark at modern understanding.

\section{Modern understanding of care}

\section{FEMININE ETHICS OF CARE}

As Allmark says there is now much nursing literature on the ethics of care. To help us begin our exploration I will look to the character of care articulated by Nel Noddings (11). Her description of the moral nature of care is widely reflected in the writings of contemporary nurses and, for example, is similar to the ethical approach adopted by the nurse writer Patricia Benner, whose views are having a profound effect on nursing today (12).

Noddings articulates a feminine perspective on care which, she believes, involves a kind of indwelling relationship, an engrossment and motivational displacement derived from feminine emotional qualities. The carer finds her true self when she chooses to become involved in caring relationships. Thus Noddings contrasts these specifically feminine caring attributes with what she perceives to be the detached, rational and analytical coolness of male thinking. She wants to emphasise the subjectivity and emotionality of caring and the uniqueness of each caring relationship.

For Noddings there is no universal or generalizable moral norm to be responded to, no principle or 'ought' of care. Here then, she refutes the rationalism of both utilitarian ethics, that care is for a particular purpose, and the Kantian ethic of duty. To demonstrate what she means she gives an example: suppose the punishment for a child's crime is being considered. The father would look to principle, to abstract and logical consideration, while the mother would look to what Noddings calls 'concretization' (13), to the individual circumstances, personal histories and feelings. 'The father might sacrifice his own child in fulfilling a principle; the mother might sacrifice any principle to preserve her child'.

Three obvious problems with Noddings's view strike us. Firstly, pace Gillon, we are faced with the inevitable conclusion that engrossed caring is somehow contrary to the basic rational nature of men. We cannot really expect men to care in the way women do because they just do not have the essential prerequisite characteristics. While we may suspect that Noddings believes men can somehow develop the 'feminine' side of their characters, this still leaves the problem of defying nature; not least we are brought to question whether women ought then to develop their 'masculine' sides, their rational, abstract and logical thinking. Even more we need to question the basic premise that caring is essentially feminine, when the very model upon which Noddings draws, Martin Buber's expression of relationship as the authentic confrontation of the I and the Thou, was, after all, famously articulated by a man. And of course, from Noddings's perspective then, Allmark's arguments could be dismissed as merely those of someone with a male identity or perhaps an underdeveloped feminine side.

But, indeed, the argument of Noddings's thesis is strongly contested by feminists such as Gillian Dalley (14) and Jane Salvage (15). Dalley believes that the idea that women are naturally caring by virtue of their psychological make-up has resulted in the expectation that women are to perform the caring tasks of society. These expectations, Dalley (16) argues, that women are best suited to the 'lonely', 'unrewarding', 'tedium' of child care, care of the elderly and care of the home, have been internalised by women themselves. 'This raises the issue of ideology and the internalising of values. A view that holds women to be caring to the point of self-sacrifice is propagated at all levels of thought and action; it figures in art and literature, it is the prop of official social welfare policies, and it is the currency in which the social exchanges within marriage and the domestic sphere are transacted. It means that women accept the validity of this view as readily as men do. And once this central tenet - of women's natural propensity to care (in contradistinction to men's nature) - is accepted, the locus for that caring then becomes determined. With woman as carer, man becomes provider; the foundation of the nuclear family is laid. It becomes the ideal model to which all should approximate'.

Salvage holds a similar perspective to Dalley, which she spells out in her argument against defining nursing as woman's work. 'The curing function is regarded as the province of doctors, usually men, and caring is the province of nurses, usually women - a gender division of labour which reflects the traditional gender stereotyping of skills and qualities. 
Decisive behaviour, rational thinking and competitiveness are seen as masculine attributes, while irrationality, docility and sacrificing personal needs are feminine attributes' (17). Noddings's thesis of gender distinctions is therefore rejected by some feminine or feminist thought itself.

Our second problem concerns Noddings's point about the emotional motivation to care. Noddings's thesis does not confront adequately the care of the stranger, which is, for us, the essence of nursing care. For Noddings seems to focus on women caring in everyday relationships - for children, parents, friends, those to whom they are bound - and therefore connected to by self-interest. But not only does she fail to reflect the reality of not caring for those tied in already existing bonds - women, for example, who subjugate personal relationships for professional growth and self-actualization - but she does not confront the arbitrariness of feelings, particularly for those with whom they have no natural affinity, no natural emotional 'feel' or interest, and with whom they feel no ties, those who are strangers. Basing an ethic of care on natural feeling opens us to responding without care when we have no natural feeling. Noddings acknowledges this kind of situation as one of guilt, but sees this as something we need to accept and even welcome as part of our nature.

This brings us to our third problem and Allmark's criticisms. In rejecting moral principles as the right or wrong of care Noddings should be left without a clear basis for the nature of care itself. The idea of care, expressed by Noddings, as engrossment and motivational displacement and resting in the subjectivity of each personal situation, cannot, in itself, distinguish between the good and the bad of that which is cared about. As Allmark has noted, the torturer 'cares' about the object of his torture. And it is obvious that Hitler 'cared' for the Aryan people and no doubt his mother 'cared' for him. They all possessed the sensitivity and skill to protect the things they cared for.

But Noddings is inconsistent. She is in fact assuming an idea of care that incorporates a conception of right and wrong although without any legs to stand it on. For if we look again at Noddings's example of the punishment quoted earlier, we note that caring does not preclude punishment or sacrifice, indeed it may even involve it. Hence Noddings presupposes a concept of care as intimately linked with justice. Allmark is right then to mention Jeffrey Blustein's criticism. For Blustein points out the inconsistency of Noddings's claim that the moral nature of care is not a given norm, but a subjective experience: 'It is difficult to understand how the claim that moral statements are derived from the caring attitude can be reconciled with the fact that we make moral demands of caring, and that caring may or may not meet these demands' (18).

The question that Noddings fails to answer, because she rejects it, is what forms the moral basis of care. This, as Allmark notes, is vital, and we might add particularly so for nurses. But whereas Allmark rejects the notion of care as having ethical import, we need to look deeper.

Noddings has built her concept of care as relationships from the Jewish theologian Martin Buber. But while she draws on Buber's understanding of relationship she rejects the foundations for this ethic. Here is the basis for her inconsistency and the root of her contradiction. For Noddings rejects 'love' or as she terms it 'agapism' [sic]. 'There is no command to love nor, indeed, any God to make the commandment. Further, I shall reject the notion of universal love, finding it unattainable in any but the most abstract sense and thus a source of distraction' (19). But Buber's (20) understanding of relationship, the authenticity of the I and the Thou, depends on the all-embracing and universal Thou, God. Buber's position is grounded therefore in the objective moral Jewish covenant tradition. Noddings has therefore cut her fruit, of caring, from the tree of its moral tradition. As Allmark argues, care no longer has a moral foundation.

And because Noddings builds her philosophy of caring with Buber's ideas as the walls, but without his basis for a foundation, her position inevitably collapses. For Buber sees the $I$ and the Thou mutuality as a responsibility because of the moral absolute, God, who is the foundation for the norm and who, therefore, commands the imperative. The I and the Thou relation is not optional, but the way that humanity is meant to live through its creation. Noddings expresses the divergence by quoting from Buber directly: 'Martin Buber says: "Love is responsibility of an I for a Thou: in this consists what cannot consist in any feeling"'. But Noddings does not want this 'ought' of care to become an escape for guilt by 'conformity and/or regard to principle'. Instead Noddings chooses 'motivational shift' and 'engrossment' as the characteristics of caring (21). She is left with nothing but the shifting sands of emotion as a basis for care.

\section{RATIONALIST ETHICS OF CARE}

Noddings has been arguing against caring as a form of duty, against the idea of the absolute norm, rational and logical principles governing the action of care. The idea of care as a moral duty as we see in the Kantian approach confronts many of the problems that we have revealed in Noddings's position. For Kant takes a rationalist approach and holds that we have a moral imperative to treat the individual with the dignity and respect due to him or her, because he or she, like me, is a moral and rational individual. As Blustein writes, unlike the utilitarians, Kant holds with the intrinsic worth of the individual regardless of his or her usefulness to society. The duty of care then is a primary moral imperative, an absolute norm.

But what of the way that care is exercised? Noddings no doubt rightly sees that Kant's position has little room for the person-to-person meeting of 
the I and the Thou. As Iris Murdoch notes (22) there is an essential area of coldness in morality, as there is an essential area of warmth. 'Seen in Kantian context, the I-Thou concept can seem (by contrast) thrilling and dramatic, readily compromised by various selfregarding consolations. It holds out a promise of experience and ever-available company'. So we see why Noddings is drawn to Buber in the face of Kant's rational coldness. But we as nurses are faced with the question as to what kind of style of care nurses should practise. We see too well with Noddings that a Kantian form of care can be cold, without human warmth; detached and dutiful, correct and philanthropic, meeting needs of patients but without 'heart'. But we have seen too, that Noddings's alternative is also flawed. Perhaps this is because the patient and the nurse are not involved in a 'complete mutual understanding'. Theirs is not a 'frank meeting' such as friends or lovers might feel. It may be false and also harmful to suggest that such mutuality can and should govern the nurse-patient relationship.

\section{The traditional understanding of care}

JUDAEO-CHRISTIAN ETHIC OF CARE

And maybe the clue to help us bridge the two kinds of attitude, what Murdoch perceives to be the warmth and coldness in morality, can be found if we look more closely at the basis of Buber's I and Thou, which has been explicitly rejected by Noddings. For as we have seen, the detached rationality of responsibility and duty, is held together with the warmth of love and compassion by virtue of their meeting in God. As Buber (23) argued against Carl Rogers, in a professional relationship in which one partner has needs which the other does not, in which one person comes for help to the other, the genuineness of relationship rests in a mutuality that is greater than both partners.

This is important for nursing. For it is disingenuous to imagine that as a nurse I am offering my patient personal friendship, when not only the temporality of the relationship, but also its intrinsically unequal nature, means that I am unable to do so. And it needs to be acknowledged, for the patient and the family, this very temporality and inequality, this necessary detachment, is its strength, security and protection for the vulnerable. Objectivity and necessary detachment need to be combined and balanced with the subjectivity and warmth of fellow feeling as true compassion. Here lies the meaning of agape, the Judaeo-Christian concept of altruistic love, stemming from the all-embracing Thou, the root of Buber's understanding for the I and the Thou in human relationships.

And, indeed, if Buber's philosophy rests in a religious dimension, we can argue that Kant too, despite his effort, does not escape the grounding of the Judaeo-Christian tradition. For Kant was raised in a profoundly Protestant Pietist culture and ethos, and as Warnock (24) argues, this is the moral outlook which he actually expounds. His view of morality is that of the Judaeo-Christian tradition. And although he chooses to try and escape the theological imperative and ground his categorical imperative in human rationality alone, as Warnock argues, this leaves his moral position hanging in the air.

And this is a major problem articulated by Allmark. For the question which we have not yet faced, but which we need to ask of both the existentialist such as Noddings, as well as the rationalist such as Kant, is the question why? Why should we care? And Allmark is not alone. This is precisely what Nietzsche (25) asked of Kant's approach. If our moral outlook is independent of external and objective norms - or perhaps as Gillon suggests, we become more mature and less absolutist in our moral understanding (26) - then in effect it is up to us to make our own morality, our way of living. And why is one way better than another? In the end it is a matter of personal preference.

For Nietzsche the answer lies in personal empowerment. He wants us to get rid of all the constraints of traditional morality that have held us back from actualizing our potential. $\mathrm{He}$ argues that now that we have discovered that God is a myth, we need to throw out ideas of morality that were influenced by this outdated notion, throw off the restrictions imposed by our Judaeo-Christian past, and take from life what we want. This calls for a radical revaluation of all values, not least the value of care for the sick and vulnerable. When people are no longer fit to fight for power, then they should take the honourable way out and exit from life. To prolong life through the fallacy of care, says Nietzsche, is of no value but is spineless and weak. In a sense then, Nietzsche is calling for a re-definition of the values and even the concept of 'care' (27). 'The sick man is a parasite of society. In a certain state it is indecent to live longer. To go on vegetating in cowardly dependence on physicians and machinations, after the meaning of life, the right to life, has been lost, that ought to prompt a profound contempt in society' (27). It may be more 'caring' not to 'care'. This view, which calls for a re-shaping of the values of society and the attitudes of us as members of society, is reflected in modernist and post-modernist philosophy from Heidegger to Foucault.

\section{Conclusion}

And this brings us back to teachers of nurses. How and what are nurses taught if, as Allmark suggests, there is no objective ethical content to the concept of 'care'? Yet, indisputably, nurse teachers do stand in a tradition. The ethics of care is no mere modern currency, but the moral tradition of which all nurses are part, stretching back through the ages, rooted in a particular view of mankind. The moral basis and thus the content and direction of care have been our 
nursing heritage, a foundational assumption however little articulated; an altruistic compassionate love concerned with the needs not only of the cheerful, helpful, and grateful patient or client, but also of people who may be unattractive, ungrateful, unhygienic, awkward and demanding. 'As you did it to one of the least of these my brethren you did it to me.' (28).

In view of the modern enigma of a caring profession now unable to define care, we need to ask ourselves whether and to what extent health care generally, and nursing particularly, is living on what the eminent surgeon, Muriel Crouch (29), has called 'borrowed capital'. Perhaps the capital is running out, as Allmark demonstrates?

Ann Bradshaw, SRN, DipN(Lond), PhD, is Macmillan Lecturer in Palliative Nursing, the National Institute for Nursing, Radcliffe Infirmary, Oxford.

\section{References}

(1) Allmark P. Can there be an ethics of care? Fournal of medical ethics $1995 ; 21$ : 19-24.

(2) See reference (1): 23.

(3) The Bible. Matthew 25:35,36.

(4) Constantelos D. Byzantine philanthropy and social welfare. New Brunswick: Rutgers University Press, 1968.

(5) Bradshaw A. Lighting the lamp: the spiritual dimension of nursing care. London: Scutari Press, 1994.

(6) Gillon R. Caring, men, women, nurses and doctors and health care ethics [editorial]. Fournal of medical ethics 1992; 18: 171-172.

(7) See reference (6): 172.

(8) Walton J. Method in medicine. Harveian oration to the Royal College of Physicians. London: Royal College of Physicians, 1990.

(9) See reference (8): 4.

(10) Berkhof H. Christian faith. Grand Rapids: Eerdmans, 1979: 515.

(11) Noddings N. Caring: a feminine approach to ethics and moral education. Berkeley: University of California Press, 1984.

(12) Benner P. The role of experience, narrative, and community in skilled ethical comportment. Advances in nursing science 1991 ; 14: 1-21.

(13) See reference (11): 37.

(14) Dalley G. Ideologies of caring. Basingstoke: Macmillan, 1988.

(15) Salvage J. The politics of nursing. London: Heinemann, 1985.

(16) See reference (14): 14-15.

(17) See reference (15): 7.

(18) Blustein J. Care and commitment. New York: Oxford University Press, 1991: 41.

(19) See reference (11): 28-29.

(20) Buber M. I and Thou. [2nd ed, trans Smith R] Edinburgh: T \& T Clark, 1958.

(21) See reference (11): 40.

(22) Murdoch I. Metaphysics as a guide to morals. Harmondsworth: Penguin, 1993: 470.

(23) Buber M. In: Kirschenbaum H, Henderson V, eds. Carl Rogers: dialogues. Constable: London, 1990: 41-63.

(24) Warnock G. Kant. In: O'Connor D, ed. $A$ critical history of western philosophy. New York: The Free Press of Glencoe, 1985: 296-318.

(25) Nietzsche F. The portable Nietzsche [Kaufmann W, ed, and trans]. Harmondsworth: Penguin, 1976.

(26) See reference (6): 172.

(27) See reference (25): 536.

(28) The Bible. Matthew 25:40.

(29) Crouch M. A basis for medical ethics. In: Vale A, ed Medicine and the Christian mind [2nd ed]. London Christian Medical Fellowship, 1980: 48-56.

\section{News and notes}

\section{Genomic Information: Ethical Implications}

This is the last time we are planning to offer this course. Sponsored by the Department of Medical History and Ethics, and the Division of Medical Genetics in the School of Medicine at the University of Washington, the course will be held in Seattle, WA, June 9-12, 1996. This intensive, advanced course will emphasize principles and methods that both scientists and ethicists can use to study and resolve ethical and social issues relevant to the Human Genome Program. To be considered, please submit completed applications by March 18, 1996. The University of Washington
School of Medicine designates this continuing medical education course for up to 28 hours of Category 1 of the Physician's Recognition Award of the American Medical Association. For information on specific objectives, and to receive a program brochure and application form, contact: Marilyn J Barnard, Program Co-ordinator; Medical History and Ethics; Box 357120; University of Washington; School of Medicine; Seattle, WA 98195-7120; Phone: (206) 616-1864; Fax: (206) 685-7515; E-MAIL: mbarnard@u.washington.edu 